\title{
Religion and Belief in the Constitutional Court Verdicts and its Implications for Sustainability of Indigenous People Belief in Indonesia
}

\author{
E Ratnaningsih \\ Faculty of Humanities, Universitas Bina Nusantara, Jakarta, Indonesia
}

ernarn@binus.ac.id

\begin{abstract}
Religious freedom is assured in the 1945 Constitution (Amendment) Article 29 and Article 28 E. Nevertheless, there are laws which restrict the religious freedom of indigenous people. The institution that has the power to correct the provision of the law is contrary to the Constitution is Constitutional Court (CC). The CC was decided on the interpretation of religion and belief on Blasphemy Law and Population Administrative Law. The purpose of this article is to define and analyze the interpretation of religion and belief in the Constitution, Legislation and Constitutional Court Verdicts. It is also examining the impact of CC Verdict for the sustainability of indigenous people belief in Indonesia. The study of this paper is normative legal research with statute, concept and analysis approach. The result of this article is $\mathrm{CC}$ verdict states that Population Administrative Law is contradicted with the Constitution. The study will support the implementation of the Constitutional Court Verdict on Population Administrative Law to make implementing regulations to give access to basic needs and to provide public services for indigenous people believe.
\end{abstract}

Keywords: Religious, Freedom, Verdict

\section{INTRODUCTION}

The discourse on religion in Indonesia is an endless debate. The pull out of interest to build Islam as the foundation of the state which is not merely took place in the Constituent Assembly of 1945 but persisted throughout the history of this Republic of Indonesia. The formulation of Article 29 is also always questioned [1].The guarantee of freedom of religion in Indonesia is very clear and firmly stated in Article 28 E Paragraph (1) and (2) of the 1945 Constitution of the Republic of Indonesia states that everyone is free to embrace religion and worship according to his religion and free to be entitled to freedom of belief, to express his thoughts and attitudes according to his conscience. Furthermore, it is also regulated in Article 29 Paragraph (2) of the 1945 Constitution which say that the state guarantees the independence of every citizen to embrace his or her own religion and to worship according to his religion and belief. The provision in the Constitution is followed by promulgate the legislations that guarantee religious freedom, namely Law Number 39 Year 1999 on Human Rights, Law Number 12 Year 2005 regarding the ratification of the International Convenant on Civil and Political Rights. 
The issues raise in this paper are the different interpretation of Article 29 and $28 \mathrm{E}$ in the 1945 Constitution (Amendment) with Law Number 1 / PNPS / 1969 on Prevention of Abuse and defamation of religion (Blasphemy Law) and Law Number 24 Year 2013 regarding the Amendment of Law Number 23 Year 2006 regarding Population Administration (Population Administration Law), the Constitutional Court Verdicts on those laws and its implications for indigenous people belief in Indonesia. The different interpretations contained in Article 29 Paragraph (2) of the 1945 Constitution which declare that the state guarantees the freedom of every citizen to embrace his or her own religion and to worship according to his religion and belief can be interpreted that his religion and beliefs are an inseparable unity. This interpretation can be seen in Blasphemy Law in its explanation states that the religions adopted by most of Indonesia's population are Islam, Christianity, Catholicism, Hinduism, Buddhism and Confucianism. This unity of interpretation causes the state not to acknowledge beliefs as a religion but as a culture. This concept makes a tension between religions which are recognized by the state and local religion which live before the state is founded. State recognition of the six religions has an effect on the difficulty of local religions developing themselves as citizen. They remain under the shadow of the issue of religious blasphemy as set out in Blasphemy Law. They are also required to accept and recognize one of the six countries that have received state legitimacy. Indigenous religions that exist long before the official religion have no choice. They enforce to join one of these religions for the sake of security and sustainability in the future.

The religious column in resident identity card also produces another stigma in Indonesia. the local beliefs that still exist in Indonesia do not recognize by the state. With the nonrecognition of local religions, the religious column in the Resident Identity Card is not filled as stated in Article 61 paragraph (1) and Article 64 of Population Administration Law. Although the service is still remain and it is only entered in the population database. The lack of religious belief written in resident identity card results in the inaccessibility of basic needs and public services of local religions to assess the rights of every citizen which are guaranteed in the constitution.

The purpose of the study is to define and analize the vagueness of religion and beliefs phrases in the Constitution, Laws and Constitutional Court verdicts and its implication for indigenous people belief. Through the Constitutional Court verdicts, the indigenous religions expect their dignity restores as the same as the rights of citizens which their religion recognized by the state. The result of this study is to support the implementation of the Constitutional Court Verdict on Population Administrative Law which recognises the identity of indigenous people on resident identity cards. The government and its apparatus should make implementing regulations from the decisions of the constitutional court on Population Administrative Law and coordinate with related institutions to provide public services for indigenous people.

\section{METHOD}

This is a normative legal research by using secondary data obtained through document studies. Legislation and court verdicts are analyzed as the main legal source in conjunction with secondary and terrier legal source. The legislative approach, case approach and conceptual approach are used to analyze the religious and belief in the Constitution, legislations and constitutional court verdicts. The method used in this study is qualitative which is descriptive data analysis method [2]. This research is done by collecting data and 
then data are grouped together according to the research problem. Data analysis is used to answer research questions and is ended with conclusions.

\section{RESULTS and DISCUSSION}

\subsection{An interpretation of Religion and Belief in the Constitutional Court Verdicts}

The Constitution does not demonstrate itself. It is quite given to a concrete political unity [3]. After the fall of the new order and the reform era, the idea of judicial review is motivated that the formulation of the law is not dominated by the interests and strength of the House of Representative and Government. This idea can be realized in the emergence of the belief that the 1945 Constitution needs to be amended [4]. The change of the position of state institutions affects the necessity of providing an institutional and constitutional mechanism to settle disputes between state institutions which have now become equal and mutually balance and control each other (checks and balances). Futhermore, it is urged that the tradition of hearing under the law contradict with the law in the Supreme Court is also given to the Constitutional Court which will conduct examine of the Law against the Constitution [5]. The Indonesian Constitutional Court has produced important constitutional success stories in the recent history. The Indonesian Constitutional Court has decided a number of crucial and polemic cases and has already launched itself as a constitutional force [6].

According to Hans Kelsen, all law is in a system that is based on the constitution as a basic norm (grundnorm). So if there are two conflicting legal norm, surely one or both of them are outside the system so that such legal norm must be considered invalid [7]. Kelsenexplains the existence of grundnorm which is the main factor to give birth of the legal regulations in a particular legal system. Grundnorm is like the fuel that drives the entire legal system. Grundnorm has a function as the basis for why the law is obeyed and responsible for the implementation of the law [8].Therefore, the provision in the Constitution that gives the right to freedom of religion, but in its implementation, are limited to their fulfillment in the law, so the mechanism adopted is to conduct a judicial review to the Constitutional Court.

One of the controversial cases in Constitutional Court is the issue of religion and belief. The applicants submit judicial review of Blashemy Law to the Constitutional Court. The Constitutional Court verdict Number 140/PUU-VII/2009 rejected the idea that mention of only six religion as set out in Article 1 of The Blasphemy Law discriminated against other religions and beliefs. The Court reasoned that although these six religions are officially supported by the State. This did not prevent or forbid a person from practising another religion and belief. Therefore, "religious values" of the six recognised religions protected under the Blashemy Law are justified by this limitation in Article $28 \mathrm{~J}$ (2) of the Constitution [9]. The impact of the rejection of judicial review on Blasphemy Law makes this law remain in force.

Discrimination in indigenous/local religions is occurred continuously with the enactment of Population Administration Law. In Article 61 paragraphs (1) and paragraph (2) in conjunction with Article 65 paragraph (4) of the Population Administration Law infringe the rights of the applicants as a citizen. In these Articles, it is stated that the description of the religious column on the resident identity card for the people whose religion has not been recognized as a religion based on statutory regulations or for the believer is not filled in but it is still served and recorded in the population database. The phrase "still served and recorded in the population data base" is unconstitutional as it results in the applicants opinion that their constitutional rights have been violated such as local religions are difficult to get birth 
certificate, married certificate, family card and also to get access of public services provided by the government.

Judicial review of the Population Administration Law on religious columns for indigenous people was proposed by four applicants from indigenous religions that still exist today namely the beliefs of Marapu, Parmalim, Ugamo and SaptoDarmo. These indigenous/local religions have followers spread across several regions of Indonesia. In their application, the petitioners considered that the Articles in the Population Administration Law have been contradictory to the articles of the 1945 Constitution. The applicants also stated that their constitutional rights to enjoy religious freedom in Indonesia have violated by misguided stigma, infidelity, atheism and even their families are denied for burial in the public cemetery etc.

The Constitutional Court provides its fundamental legal considerations in the verdict of the Court Number 39 / PUU-XIV / 2016 concerning the Population Administration Law. In the Article 61 paragraph (1) and paragraph (2) and Article 64 paragraph (1) and paragraph (5) are of the opinion that the religion in question is a recognized religion in accordance with the laws and regulations. Consequently, the constitutional responsibility or obligation of the state to guarantee and protect the right to freedom of citizens to embrace a religion which also includes trust of God is also limited to citizens who follow a religion that is recognized by the state in accordance with the provisions of laws and regulations. This is not in conformity with the spirit of the 1945 Constitution which ensures that every citizen is free to embrace religion and belief and to worship according to his religion and belief. The Court also says in their decision that with the notion of terminology of "religion" in Article 61 paragraph (1) and Article 64 paragraph (1) of the Population Administration Law including belief then by itself the norms of these Articles do not provide equitable recognition, guarantee, protection and legal certainty and equal treatment before the law for indigenous people of God compare to religions which recognized by state namely "religion recognized as a religion in accordance with the provisions of legislation".

Futhermore, in fact the existence of Article 61 paragraphs (1) and (2) and Article 64 paragraph (1) and paragraph (5) of the Population Administration Law have in fact caused uncertainty, different interpretations and inconsistencies with other norms in the same law as Article 58 paragraph (2) where it gives effect that citizens of indiginous beliefs have difficulty obtaining family card and electronic resident identity card. With the removal of the demographic data element of religion also has an effect on the fulfillment of other rights, such as marriage and population services. Thus, Indigenous people are not guaranteed certainty and equality before the law and government as acquired by other citizens. At the same time, such a matter is a loss of the constitutional rights of citizens which should not have been occurred. Occasions experienced by the applicants where they have difficulty getting a job, it is not a matter of implementation of the norm but a logical consequence of the notion of "religion" adhered to by the Population Administration Law that does not include the believer of God as part of it.

Based on the above legal considerations, the Constitutional Court granted the judicial review of Article 61 paragraph (1) and (2) and Article 65 of the Population Administration Law which became the basis of the Government to empty the religious data columns on the resident identity card and family card of the indigenous people belief. The Constitutional Court declares those articles to be contrary to the constitution if the religious phrases in it are not implicit, including belief. The expression of "unconstitutional" has as applied to law at least three different meanings varying according to the nature of the constitution with reference to which it is used : firtsly, the phrase as applied to English Law of Parliament it cannot mean that the Law is either a breach of law or is void. Secondly, The phrase as applied 
to a law passed by the French Parliament, it does not necessarily mean that the law is question is void. Lastly, the phrase as applied to an Law of Congress intends simply that the Law is one beyond the power of congress and is therefore void. Without any inconsistency, a Law of Congress is a good law [10]. In Indonesia context, The law is unconstitutional if the law do not consistent with the Constitution. It means that the law is contradictive with the Constitution 1945 and it has no binding power.

\subsection{The Implication of Constitutional Court Verdicts for Suistainability of Indigenous People Belief in Indonesia}

In the Constitutional Court verdict, the applicants feel their constitutional rights violated by the implementation of some articles in the Population Administration Law namely: a. Marriage between indigenous people belief is not recognized by the state as a result their children find it difficult to obtain a birth certificate; b. Local religious followers cannot access population documents such as electronic resident identity card, family card, marriage certificate; c. indigenous people belief are often forced to choose a recognized religion by the state in order to obtain resident identity card and also to attend religious studies at school; d. Some applicants whose children are refused to apply for a job even though their grades and achievements are good because prospective employers consider the dash marks in the resident identity card to be identical to atheists or infidels; e. The applicant cannot access business capital from financial institutions; f. The local religious community is rated / branded as oldfashioned, infidel and heretical; g. The family funeral of the applicant was rejected at any public cemetery.

This situation already reported to the United Nations and the Universal Periodic Review in the Session 27, May 2017 already made recommendation in religious freedom implementation in Indonesia such as the state of Indonesia shall promptly take measure to recognize and protect the rights of indigenous peoples to identify with and practice their indigenous religion and belief, as well as to get rights of identity as a citizen and other social services without any discrimination in law or practice in line with the recommendation of CERD. A special program shall be put in place immediately. In cooperation with the Komnas HAM and Indigenous people, to ensure that those who were forced to convert from their religion can have the freedom to choose to go back to their former religion as they wish [11].

Constitutional Court Verdict concerning Population Administration makes the indigenous people have identity with putting their belief in resident identity card. The recommendation of the UPR has been fulfilled by protecting the rights of indigenous people belief to get identity on their resident identity card and get other social services without discrimination. It has been in accordance with the provision in Article 12.1 of the United Nations Declaration on the Rights of Indigenous Peoples (UNDRIP) stated: "Indigenous Peoples have the rights to manifest, practice, develop and teach their spiritual and religious traditions, custom and ceremonies: the rights to maintain, protect, and have access to privacy to their religious and cultural sites, the rights to the repatriation of their human remains". The Constitutional Court's verdict on Population Administrations Laws restores the position of the indigenous people to enjoy their beliefs which have the same rights as the six religions recognized by the state and enjoy the same rights as other citizens. It will have an impact on the practicing of indigenous peoples belief in their daily life and will encourage the development and sustainability of local religious adherents.

The discourse of sustainability is permeated with religious elements from roots to shoots. Thus, while suitability movements are not all about religion, they certainly utilize religious 
metaphor and imagery and call for the reassessment of the meta-objectives of particular cultural groups. They are both analogically related to religious movements and genealogically related to religious belief and practices. Sustainability is reflective of the community specific practices and values that people wish to sustain [12]. According to Nggay Mehang Tana, the applicant in a judicial review which is a follower of the Marapu faith stated that the very fast and systematic proclamation of modern religions with their superiority led to Marapu's belief being increasingly pressed and depressed. This is strengthened by adhering to modern religion having greater access and opportunities to progress and develop. With the Constitutional Court's decision on the indigenous people belief will practice their belief without fear getting discrimination in access resident identity card, marriage certificates, birth certificates and other public services. It is in line with sustainable development goal 16 which state birth registration is a first step towards safeguarding individual rights and providing every person with access to justice and social services [13].The inclusion of a belief column in the resident identity card will result indigenous people married being recognized and obtaining a marriage certificate. Then their children will have a birth certificate. With the inclusion of religious beliefs in the identity card, indigenous people are not forced to choose one of the religions recognized by the state as an excuse to obtain the basic rights and civil rights of citizens. This will indirectly result in the sustainability of indigenous religious beliefs in Indonesia.

\section{CONCLUSION}

Indonesia has a constitution and legislations that guarantee the rights of religious freedom. Nevertheless, there are still laws that restrict and limit freedom of religion in Indonesia such as Blasphemy Law and Population Administration Law. Members of local religious beliefs who feel these Laws violate their constitutional rights may submit a judicial review to the Constitutional Court. In the Blasphemy Law, Constitutional Court rejected judicial review of the applicants. Therefore, the state continuously recognised only six religions. Whereas, the Constitutional Court granted the judicial review of applicants which declare those Articles in Population Administration Law to be contrary to the constitution if the religious phrases in it are not implicitly including belief. Although the verdict of the Constitutional Court is only related to the emptying of the religion column on the resident identity card and family card, it implies that the state recognizes the right to life of indigenous people and it will impact on the sustainability of indigenous people belief to practice, manifest, develop and teach their spiritual and religious tradition In addition, the government and its apparatus has obligation immediately to improve the system of population administration as well as equal services to accommodate the recognition of the local indigenous people belief in Indonesia. The relevant government officials should respect the verdict of the Constitutional Court and implement this verdict by coordinating the mechanism of recording the local religious or indigenous religions with the relevant institutions.

\section{REFERENCES}

[1] S. M. Mulia, Menuju kebebasan beragama di Indonesia Kebebasan beragama atau 
berkepercayaan di Indonesia. Jakarta: Komnas HAM, 2006.

[2] S. Soekanto, "Masalah-Masalah di Ssekitar Perundang-Undangan (Suatu tinjauan menurut sosiologi hukum)," J. Huk. Pembang., vol. 6, no. 1, p. 27, Mar. 1976.

[3] S. Carl, Constitutional Theory. United States: Duke University Press, 2008.

[4] M. Mahfud, Membangun politik hukum, menegakkan konstitusi. Jakarta: Rajawali Pers, 2011.

[5] J. Asshiddiqie, Menuju negara hukum yang demokratis. Jakarta: Bhuana Ilmu Populer, 2009.

[6] J. Menzel, Constitutionalism in Southeast Asia: Some comparative perspectives Constitutionalism in Southeast Asia. Singapore: Konrad Adenauer Stiftung, 2010.

[7] F. Munir, Teori-Teori Besar (Grand Theory) dalam Hukum. Jakarta: Prenadamedia, 2013.

[8] A. Achmad, Menguak Teori Hukum (Legal Theory) dan Teori Peradilan (Judicial prudence) termasuk interpretasi Undang-Undang (Legisprudence). Jakarta: Prenada Media Group, 2009.

[9] M. A. Crouch, "Law and Religion in Indonesia: The Constitutional Court and the Blasphemy Law," Asian J. Comp. Law, vol. 7, pp. 1-46, Apr. 2012.

[10] A. C. Divey, Introduction to the study of the law of the Constitution. London: Liberty Classics, 1915.

[11] UPR Info, "Indigenous People in Indonesia," UPR Info, 2017. [Online]. Available: https://www.upr-info.org/sites/default/files/document/indonesia/session_27_may_2017/aman_upr27 idn_e_main.pdf.

[12] $\bar{L}$. F. Johnston, "Sustainability as a Global Faith? The Religious Dimensions of Sustainability and Personal Risk," J. Am. Acad. Relig., vol. 82, no. 1, pp. 47-69, Mar. 2014.

[13] United Nations, "Suistainable development goal 16," United Nations, 2018. [Online]. Available: https://sustainabledevelopment.un.org/sdg16. 